\title{
Ability and its Enhancement of Employees of Foreign Trade Enterprises
}

\author{
Jinchao Wang \\ Jilin Agricultural University, Changchun Jilin, 130118 , China
}

Keywords: Foreign trade enterprise, Employees' ability, Enhancement.

\begin{abstract}
As China's level of foreign trade rises, the needs for various talents are also increase continuously and foreign trade enterprises also ceaselessly intensify the cultivation of the quality of their employees. Therefore, faced with the fiercer competitive environment on the international market, how to enhance the ability of employees of foreign trade enterprises is a problem concerned by foreign trade enterprise for a period of time. This paper analyzes the current situation of ability of employees at foreign trade enterprises and existing problems, and reflects on how to enhance the ability of employees of foreign trade enterprises.
\end{abstract}

\section{Introduction}

Since the implementation of economic reform and opening-up policy in China, China's rate of economic growth has been increasing significantly. With the rapid development of China's economy, our country has also become the leading powerful manufacturing country in the world. Besides, "made in China" has also become a powerful business card of our country. After China became a powerful manufacturing country, the foreign trade has also become an important impetus for the development of economy in China. The development of foreign trade is one of the important embodiments of a country's overall economic strength and has also made great contributions to the rapid development of China's economy in recent decades. In addition, the development of foreign trade also leads to the continuously growing need for talents in the sector of foreign trade, especially the great demand for foreign trade talents with very strong ability. As China's foreign trade was started after reform and opening up so its development duration of foreign trade is not short; for this reason, there are many shortcomings in the reserve and cultivation of foreign trade talents. This is directly shown in the ability shortage of employees at foreign trade enterprises. Their ability shortage not only directly affects the development of a foreign trade enterprise but also affects the development of China's foreign trade to some extent. The foreign trade which is not a traditional Chinese industry needs working internationally, so it has very high ability requirements for employees at foreign trade enterprises. For instance, firstly, employees should have certain foreign language ability and be familiar with the flow of foreign trade as well as the legal knowledge about specific trade. All of these can show the ability of employees of foreign trade enterprises.

\section{Inadequacies in the ability of employees of foreign trade enterprises in China}

\section{Lack of foreign language ability}

Since employees need to communicate with foreign customers internationally and read and write foreign materials etc. in foreign trade, foreign trade enterprises need the reserve of foreign language talents concerned. Besides, employees of foreign trade enterprises need to have the foreign language ability which is different from that of translators, because they also need to proficiently master the foreign language knowledge related to foreign trade. However, the current situation of ability of employees of foreign trade enterprises in China shows their severe lack of foreign language ability, 
which is specifically manifested in the lack of speaking ability and writing ability. Although China's foreign trade enterprises have been aware of the significance of reserving related talents with foreign language ability, they still don't do enough in the reserve of talents; besides, based on the gap of talents concerned in China, it is also very difficult for foreign trade enterprises to rapidly reserve related talents and solve this contradiction. From the perspective of internal aspects of enterprises, most foreign trade enterprises in China started late so their employees lack foreign language ability; in addition, some foreign trade enterprises don't attach importance to the foreign language training for employees, so the employees' foreign trade ability cannot meet the need of the development of enterprises; especially, in the current condition of diversified development of foreign trade enterprises in China, it is very difficult for the pure communication in English to adapt to the current foreign trade development situation ${ }^{[1]}$. The continuous expansion and development of China's foreign trade enterprises also lead to the increasingly prominent problem of the foreign trade employees' lack of foreign language ability.

\section{Lack of trade knowledge}

The majority of employees of foreign trade enterprises in China obtain individual development with the development of foreign trade enterprises; that is to say, a considerable number of foreign trade employees were not engaged in related business before they were employed by their foreign trade enterprises and they entered this sector after the emergence of foreign trade enterprises. For this reason, they didn't systematically learn the related trade knowledge, especially the knowledge about foreign trade. This issue is becoming continuously prominent with the development of China's foreign trade. After China joined the WTO, all sorts of trade behaviors were standardized, resulting in a huge challenge for the development of China's foreign trade. In order to standardize their behaviors and make them to conform to the requirements of all trade rules of WTO, there are high requirements for the ability of employees of foreign trade enterprises. After the trade behaviors of China's foreign trade enterprises were standardized, their employees' trade knowledge ability became an important aspect to guarantee the normal operation and development of foreign trade enterprises. Therefore, employees of foreign trade enterprises need to know all trade rules of WTO, legal knowledge concerning international trade and conventional handling methods for any trade disputes incurred etc. However, the employees of foreign trade enterprise of China exactly lack the trade knowledge in such aspects ${ }^{[2]}$. Due to the short development period of China's foreign trade and the large gap in the reserve of related talents, the talents who are proficient in related trade knowledge become the objects competed for by all foreign trade enterprises. As for foreign trade enterprises, they don't pay enough attention to enhancing their existing employees' related trade knowledge ability and don't provide systematic training schemes; as a result, it is very difficult for their employees' trade knowledge to meet the development need of the current enterprises.

\section{Lack of experience}

The ability shortage of employees of foreign trade enterprises in China is also shown in their lack of experience, which is directly manifested in that some employees of foreign trade enterprises fail to proficiently master all links and flows of a trade when handling the international trade, extremely easily cause all sorts of leakages during trade and even result in great losses to the enterprises. In the process of international trade, a foreign trade enterprise should handle all links in the trade process extremely prudently and should pay more attention to the places which easily cause issues and disputes in particular. This also requires that their employees concerned should have rich experience in foreign trade. However, in China, it is a general situation that employees of foreign trade enterprises lack experience; especially, some university graduates majoring in foreign trade recruited by some companies largely lack practical operations; meanwhile, some experienced old employees didn't systematically learn the foreign trade knowledge; therefore, a crossover bug between them was caused. The foreign trade enterprise employees' lack of experience in foreign trade also will result in enterprises' failure to take rapid and proper treatment measures for any foreign trade dispute incurred; as a result, such a dispute may expand continuously and even cause invocatable losses to enterprises. 
From the perspective of some dispute cases in China's foreign trade enterprises, many of them were caused by enterprise employees' lack of experience in foreign trade; or we can say that they failed to minimize their enterprises' losses within the shortest time after the occurrence of disputes.

\section{Enhancing the ability of employees of foreign trade enterprises}

\section{Enhancing foreign language training for employees}

As far as a foreign trade enterprise is concerned, the reserve of related talents with foreign language ability is of vital significance for guaranteeing the development of an enterprise. The reserve of talents is mainly shown in two aspects. Firstly, introduce related talents; secondly, provide foreign language training for employees inside an enterprise. In consideration of all aspects of the development of an enterprise, conducting foreign language training for its employees is undoubtedly the best way, because this can not only guarantee that its employees who have certain trade knowledge and experience can improve their foreign language ability simultaneously, but also can help employees to combine their foreign language ability with their foreign trade work to get twofold results with the half the effort. Besides, this can also reduce an enterprise's human cost to some extent, so providing employees with foreign language training is also a usual practice in foreign trade enterprises. The foreign language training for employees should be conducted mainly in two aspects. Namely, it is required to not only improve employees' ability to speak foreign languages but also improve their ability to read and write materials concerning foreign trade. As for as a foreign trade enterprise is concerned, it can periodically organize its employees to accept systematic training for a period of time, conduct assessment after the end of their training and connect their assessment results with their work performance to urge them to learn a foreign language consciously. In addition, an enterprise, perhaps, can stimulate employees' learning initiative and thus enhance the effect of foreign language training for employees by promoting those who get high assessment credits ${ }^{[3]}$.

\section{Strengthening trade knowledge training for employees}

Since a considerable part of employees of foreign trade enterprise of China didn't systematically learn trade knowledge, this shortcoming can be overcame by strengthening employee training inside of enterprises. An enterprise may hire related lecturers and experts to guide in the enterprise or organize its employees for systematic course learning so as to strengthen the trade knowledge training for the employees. In addition, a foreign trade enterprise should have correct understanding of its employees' trade knowledge ability. In particular, after China joined the WTO, we can say that the employees' trade knowledge ability can largely influence the development of an enterprise. The decision-making level of an enterprise should have correct understanding of this and thus actively organize employees for training. As for the training mode, employees may be trained systematically by training institutions or attend related courses given by some entrusted colleges through cooperation with colleges. At present, it is an important way to entrust colleges to teach the trade course for employees. Such a mode with the cooperation between enterprises and colleges is also a present brand-new training mode and can greatly make up for the deficiency that employees didn't systematically learn trade knowledge. Besides, this can also largely help for the long-term development of an enterprise, fully guarantees a foreign trade enterprise's need for related personnel and safeguards the expansion and development of an enterprise.

\section{Strengthening employees' business practice}

Improving a foreign trade enterprise's business ability and its employees' experience in business practice is also an important aspect for enhancing a foreign trade enterprise's business level. In order to solve the problem that employees of foreign trade enterprises generally lack business experience, an enterprise needs to consciously cultivate and train new employees and enhance its employees' business practice ability in daily work. As foreign trade is a business involving many fields, employees can obtain practical experience in many aspects. Therefore, employees can continuously 
learn, make progress and improve themselves when operating foreign trade so as to obtain good individual development. A foreign trade enterprise should consciously cultivate and train its employees who don't have rich business experience and let the experienced employees to guide the new ones. For instance, the enterprise may provide its experienced employees with assistants so that the new employees can rapidly obtain chances for learning and practice to enrich their own business experience. Meanwhile, an enterprise can also organize its employees to learn various cases regarding foreign trade at home and abroad so that employees can obtain some experience, especially the experience in dealing with a trade dispute. Both an enterprise and its employees need to make efforts together to strengthen the business practice. An enterprise should provide its employees with a sufficient space and stage to show themselves. Employees should actively learn and improve themselves.

\section{Conclusion}

In recent years, China's foreign trade develops swiftly and great achievements have been made. For this reason, some foreign trade enterprises also obtained great development opportunities and won success. However, there are also some problems in the development process of China's foreign trade enterprises. Employees' ability shortage, which is a very outstanding problem, has greatly influenced the development of an enterprise. To guarantee the long-term development of foreign trade enterprises and facilitate the steady development of China's foreign trade, it is extremely necessary to enhance the ability of employees of foreign trade enterprises. The enhancement of employees' ability should be started from various aspects, such as employees' foreign language ability, reserve of trade knowledge and business ability. Enterprises should understand that talents are the most precious property of enterprises and this is all the more so in the sector of foreign trade. Therefore, foreign trade enterprises should correctly understand this and actively take various actions to enhance the employees' ability to safeguard the development of enterprises.

\section{References}

[1] Liu Hui. Brief discussion on the training for employees of foreign trade enterprises, Journal of Taishan Township Enterprise Workers' University, 2006,04:14-15.

[2] Tang Haisong. Thought on enhancing the effectiveness of employee motivation in foreign trade enterprises, Enterprise Vitality, 2008,10:66-67.

[3] Zhang Zengkun. Research on incentive measures for core business personnel of foreign trade enterprises, Ocean University of China, 2009. 